\title{
Resolution of the age structure of the detrital zircon populations of two Lower Cretaceous sandstones from the Weald of England by fission track dating
}

\author{
A. J. HURFORD*, F. J. FITCH† \& A. CLARKE† \\ *Laboratory for Isotope Geology, University of Bern, Erlachstrasse 9a, 3012 Bern, Switzerland \\ †Department of Geology, Birkbeck College, University of London, 7/15 Gresse Street, London WIP IPA
}

(Received 22 July 1983; accepted 24 October 1983)

\begin{abstract}
Modes in the frequency of distribution of fission track ages obtained from detrital zircon grains may prove characteristic of individual sandstone bodies, supporting the identification of the sources from which a particular flow of sedimentary detritus was derived and thus allowing new inferences to be made concerning palaeogeography. A computer program has been written and used to identify modes in the zircon fission track age distribution within two Lower Cretaceous sandstone samples from the Weald of southern England. Pronounced modes appear in one rock around 119 $\mathrm{Ma}, 160 \mathrm{Ma}, 243 \mathrm{Ma}$ and $309 \mathrm{Ma}$ and in the other around $141 \mathrm{Ma}, 175 \mathrm{Ma}, 257$ to $277 \mathrm{Ma}$ and 394 to $453 \mathrm{Ma}$. The geological implications of these quite dissimilar zircon age spectra are discussed. It is concluded that they support the palaeogeographical models of Allen (1981) and indicate that the provenance of the first sample, from the Top Ashdown Sandstone member at Dallington in East Sussex, was almost entirely southerly, while that of the second, from the Netherside Sand member at Northchapel in West Sussex, was more varied, but predominantly westerly and northerly.
\end{abstract}

\section{Introduction}

The external detector fission track dating method can be used to date individual zircon crystals extracted from a sediment. Statistical evaluation of the individual zircon ages obtained from a detrital population may suggest connection with possible source areas and, thus, assist in palaeogeographic reconstruction. In this study the approach has been applied to zircons separated from samples of two Lower Cretaceous (Wealden) sandstones from Sussex in southern England, kindly made available by P. Allen of Reading University. Analysis of the measured zircon ages, with their estimated statistical errors, makes it possible to determine the probability of occurrence of crystals possessing ages within given intervals.

In his latest provincial model for the Wealden of southern England, Allen (1981) envisages a broad, shallow sedimentary basin bordered by tectonically active, block-faulted, source massifs. Internal tectonism of the same kind may have divided the basin into sub-basins at times. Upfaulting of the bordering massifs generated sandy outwash plains; downfaulting, with concomitant lessening of the relief contrast, led to the development of muddy lake-lagoon-bay environments. The clastic detritus was very largely derived from the erosion of outcrops of old sediments (with some volcanic horizons) underlying thick soils or directly exposed in deep river valleys within the massifs. The principal source areas of the Wealden sediments are thought to have been (i) Londinia to the north, exposing mostly Lower Palaeozoic, Old Red
Sandstone, Lower Carboniferous and Upper Jurassic rocks, (ii) Armorica to the south, exposing Precambrian as well as extensive outcrops of Permo-Triassic and Jurassic rocks and (iii) Cornubia to the west, exposing a sequence of Carboniferous, Permo-Triassic and Upper Jurassic rocks. Further to the northwest, both Lower and Upper Palaeozoic rocks were exposed in Hibernia. At times, incursions of the Boreal Sea along the northwestern margin of Londinia may have brought into the Weald sediment ultimately derived from northern Britain and the northern North Sea area. Contemporaneous Lower Cretaceous volcanism is known to have occurred in the Channel Approaches and in the North Sea (Dixon, Fitton \& Frost, 1981) and there may have been other nearby centres.

\section{Experimental procedure}

Zircons were separated from two crushed samples of Wealden sandstone using conventional panning, heavy liquid and magnetic techniques. Sample BK $1762(5 \mathrm{~kg})$ came from the Top Ashdown Sandstone member of the Ashdown Beds Formation, outcropping in a shaw east of Hoad's Wood, $1.2 \mathrm{~km}$ southwest of the parish church of Dallington in East Sussex (TQ 648185). The rock is lower Wealden, presumably early Valanginian, in age. The analysed material is part of a bulk sample (AWJ 54, locality 14 of Allen, 1947) collected and described by Allen (1949, 1959,1981 ). A ferruginous sandstone of medium grade carrying reworked glauconite, it does not differ significantly from the description given by Allen in 1949.

Sample BK $1761(2 \mathrm{~kg})$ came from the Netherside 
Sand member of the Weald Clay Group $0.36 \mathrm{~km}$ east of Upper Diddesfold Farm, Northchapel, West Sussex (SU 945298). This horizon is upper Wealden, presumably Hauterivian or Barremian in age. The sampled rock is, again, a ferruginous sandstone of medium grade originally collected by Allen. Detrital tourmaline from this sandstone has been dated previously by the argon-40/argon-39 technique (see below and Allen, 1975 , p. 430 , sample no. S 8052 ).

The separated zircon crystals were mounted in FEP Teflon, polished and etched in $\mathrm{KOH} / \mathrm{NaOH}$ eutectic melt at $230{ }^{\circ} \mathrm{C}$ for sufficient time to fully reveal the spontaneous fission tracks, usually between five and ten hours (Gleadow, Hurford \& Quaife, 1976). The zircon mounts were then irradiated, each in close contact with a muscovite detector, in the thermal neutron facility $\mathrm{Jl}$ of the Herald reactor at Aldermaston, UK, following the procedures of Hurford \& Gleadow (1977). The neutron fluence was monitored by cobalt activation wires, by the inclusion of the NBS dosimeter glass SRM 612, and on the first occasion by including a zircon age standard. After irradiation the external mica detectors were etched in $48 \% \mathrm{HF}$ at $20^{\circ} \mathrm{C}$ for $30 \mathrm{~min}$, to fully reveal the neutron-induced tracks.

For a given crystal, tracks were counted over identical areas of the crystal and its mica detector, using a magnification of 1563 times, under oil immersion. Tracks were counted using a calibrated eyepiece graticule, selecting only zircons with welletched faces parallel to the $c$ crystallographic axis and possessing low bulk etch rates, the criteria being the visual appearance of the track and the presence of sharply etched polishing scratches with widths less than $1.5 \mu \mathrm{m}$. Gleadow \& Lovering (1977) have demonstrated that for such crystals a geometry factor of 0.5 is valid for the ratio of track density on an external detector $(2 \pi)$ to the track density on an internal surface $(4 \pi)$. The spontaneous-to-induced track count ratio $\left(N_{\mathrm{s}} / N_{\mathrm{i}}\right)$ was then available for each crystal, allowing its age to be estimated using the zeta calibration approach (Hurford \& Green, 1981). Hurford \& Green (1983) describe the repeated evaluation over seven years of a $\zeta$ factor for dosimeter glass SRM 612 using four zircons of known age. A grand weighted mean $\zeta_{612}$ value of $339 \pm 10(2 \sigma)$ was derived and has been used in this study.

A probability distribution of the real age about an estimated age requires the use of a notional standard deviation (the 'conventional error' of Green, 1981) which is estimated from the radioactivity counts:

$$
\text { s. d. }=T \sqrt{ }\left(\frac{1}{N_{\mathrm{s}}}+\frac{1}{N_{\mathrm{i}}}+\frac{1}{N_{\mathrm{d}}}\right)
$$

where $N_{\mathrm{s}}, N_{\mathrm{i}}$ and $N_{\mathrm{d}}$ are respectively the spontaneous, induced and SRM 612 detector counts and $T$ is the estimated age. A computer was programmed to establish a normal distribution of probability density against age for each zircon, using an expression of the form

$$
C=\frac{1}{\sqrt{ }(2 \pi) \sigma} \exp ^{-\left[(T-x)^{2} / 2 \sigma^{2}\right]}
$$

where $\sigma$ is the notional s.d., calculated as above. The individual probability distributions were summed to form a weighted histogram for the whole zircon population, showing the probable frequency of occurrence of crystals within given age intervals. The form of such histograms is illustrated in Figures $1 a$, etc., to be discussed below.

\section{Results}

Ninety zircons were counted from sample BK 1762 and 44 from BK 1761, with the results set out in Tables 1 and 2. Figures 1 and 2 show the total histograms obtained from the computer analysis. Figures $1 a$ and $2 a$ represent the summation of the individual probability distributions for each zircon over the total number of zircons in the sample, applying the notional s.d. to each as described above. In Figures $1 b$ and $2 b$ the discrimination has been enhanced by halving each of the s.d.s. Figures $2 c$ and $2 d$ are repeats of Figure $2 a$ and $2 b$ but omitting ten crystals (marked ' $\mathrm{e}$ ' in Table 2) which were slightly below the quality of etching which we would normally select for counting (as described above). The modes identified in the analyses, with the relative heights of their maxima, are set out in Table 3.

For BK 1762 Figure $1 a$ indicates a concentration of ages around and below $163 \mathrm{Ma}$ (late mid-Jurassic). The increased resolution of Figure $1 b$ suggests a pronounced mode around $160 \mathrm{Ma}$ and lesser modes around $119 \mathrm{Ma}$ (mid Lower Cretaceous), $243 \mathrm{Ma}$ (late Permian/early Triassic) and $309 \mathrm{Ma}$ (late Carboniferous). There are also indications of older material, some perhaps going beyond $700 \mathrm{Ma}$ (see Table 1, e.g. HS 14, HS 47, ZJ 21, ZL 13).

For BK 1761 Figure $2 a$ indicates ages concentrated around $179 \mathrm{Ma}$ (early mid Jurassic) and $253 \mathrm{Ma}$ (Permian). The greater resolution of Figure $2 b$ suggests that the main mode is a little lower $(173 \mathrm{Ma})$ and the next most pronounced around and above $257 \mathrm{Ma}$, with another around $141 \mathrm{Ma}$ (late Jurassic/ earliest Cretaceous). There is also evidence of older material, between 393 and $475 \mathrm{Ma}$ (Devonian to Ordovician) and some older than $500 \mathrm{Ma}$ (see Table 2, e.g. AA 10, EE 6).

Figures $2 c$ and $2 d$ show the effect of omitting the ten slightly sub-quality crystals (which had been included in an effort to achieve an adequate sample in a rock with few good-quality zircons). The modes indicated by the increased resolution of Figure $2 d$ are at $141 \mathrm{Ma}, 175 \mathrm{Ma}, 277 \mathrm{Ma}$ (Lower Permian) and 398-453 Ma. Except that the $257 \mathrm{Ma}$ mode now appears rather higher $(277 \mathrm{Ma})$, the results from the two sizes of sample are substantially in agreement. The 
Table 1. Results of fission track dating of detrital zircon grains extracted from a sample (BK 1762) of the Top Ashdown Sand

\begin{tabular}{|c|c|c|c|c|c|c|}
\hline Crystal & $N_{\mathrm{s}}$ & $N_{\mathrm{i}}$ & Irradiation & $\begin{array}{l}\rho_{\mathrm{d}} / 10^{5 *} \\
\left(\mathrm{t} \mathrm{cm}^{-2}\right)\end{array}$ & $\begin{array}{c}\text { Age } \\
(\mathrm{Ma})\end{array}$ & $\begin{array}{l}\text { s.d. } \\
\text { (Ma) }\end{array}$ \\
\hline HS 1 & 266 & 65 & FTD 84 & $3.313(2520)$ & 226 & 32 \\
\hline HS 2 & 139 & 48 & FTD 84 & $3.313(2520)$ & 161 & 27 \\
\hline HS 3 & 348 & 52 & FTD 84 & $3.313(2520)$ & 365 & 55 \\
\hline HS 4 & 191 & 57 & FTD 84 & $3.313(2520)$ & 185 & 28 \\
\hline HS 5 & 118 & 45 & FTD 84 & $3.313(2520)$ & 146 & 26 \\
\hline HS 6 & 282 & 39 & FTD 84 & $3.313(2520)$ & 394 & 68 \\
\hline HS 7 & 139 & 55 & FTD 84 & $3.313 \cdot(2520)$ & 140 & 23 \\
\hline HS 8 & 48 & 14 & FTD 84 & $3.313(2520)$ & 190 & 58 \\
\hline HS 9 & 231 & 19 & FTD 84 & $3.313(2520)$ & 649 & 155 \\
\hline HS 10 & 165 & 31 & FTD 84 & $3.313(2520)$ & 292 & 57 \\
\hline HS 11 & 187 & 39 & FTD 84 & $3.313(2520)$ & 264 & 47 \\
\hline HS 12 & 131 & 65 & FTD 84 & $3.313(2520)$ & 112 & 17 \\
\hline HS 13 & 136 & 14 & FTD 84 & $3.313(2520)$ & 524 & 147 \\
\hline HS 14 & 213 & 15 & FTD 84 & $3.313(2520)$ & 752 & 201 \\
\hline HS 15 & 217 & 116 & FTD 84 & $3.313(2520)$ & 104 & 12 \\
\hline HS 16 & 69 & 37 & FTD 84 & $3.313(2520)$ & 104 & 21 \\
\hline HS 18 & 135 & 36 & FTD 84 & $3.313(2520)$ & 207 & 39 \\
\hline HS 19 & 199 & 115 & FTD 84 & $3.313(2520)$ & 96 & 11 \\
\hline HS 20 & 210 & 49 & FTD 84 & $3.313(2520)$ & 236 & 38 \\
\hline HS 21 & 52 & 19 & FTD 84 & $3.313(2520)$ & 152 & 41 \\
\hline HS 22 & 125 & 24 & FTD 84 & $3.313(2520)$ & 286 & 64 \\
\hline HS 23 & 345 & 75 & FTD 84 & $3.313(2520)$ & 253 & 33 \\
\hline HS 24 & 197 & .37 & FTD 84 & $3.313(2520)$ & 292 & 53 \\
\hline HS 25 & 423 & 57 & FTD 84 & $3.313(2520)$ & 404 & 58 \\
\hline HS 26 & 253 & 33 & FTD 84 & $3.313(2520)$ & 417 & 78 \\
\hline HS 27 & 125 & 20 & FTD 84 & $3.313(2520)$ & 342 & 83 \\
\hline HS 28 & 119 & 36 & FTD 84 & $3.313(2520)$ & 183 & 35 \\
\hline HS 29 & 114 & 38 & FTD 84 & $3.313(2520)$ & 166 & 31 \\
\hline HS 30 & 210 & 20 & FTD 84 & $3.313(2520)$ & 564 & 132 \\
\hline HS 31 & 319 & 26 & FTD 84 & $3.313(2520)$ & 655 & 134 \\
\hline HS 32 & 316 & 60 & FTD 84 & $3.313(2520)$ & 289 & 41 \\
\hline HS 33 & 150 & 45 & FTD 84 & $3.313(2520)$ & 184 & 32 \\
\hline HS 34 & 202 & 47 & FTD 84 & $3.313(2520)$ & 237 & 39 \\
\hline HS 35 & 283 & 32 & FTD 84 & $3.313(2520)$ & 478 & 90 \\
\hline HS 36 & 113 & 33 & FTD 84 & $3.313(2520)$ & 189 & 38 \\
\hline HS 37 & 262 & 57 & FTD 84 & $3.313(2520)$ & 253 & 37 \\
\hline HS 38 & 368 & 67 & FTD 84 & $3.313(2520)$ & 301 & 40 \\
\hline HS 39 & 195 & 51 & FTD 76 & $3.186(2440)$ & 203 & 32 \\
\hline HS 40 & 230 & 20 & FTD 76 & $3.186(2440)$ & 593 & 139 \\
\hline HS 41 & 269 & 45 & FTD 76 & $3.186(2440)$ & 315 & 51 \\
\hline HS 42 & 250 & 75 & FTD 76 & $3.186(2440)$ & 178 & 24 \\
\hline HS 43 & 247 & 39 & FTD 76 & $3.186(2440)$ & 333 & 58 \\
\hline HS 44 & 283 & 88 & FTD 76 & $3.186(2440)$ & 171 & 21 \\
\hline HS 45 & 358 & 33 & FTD 76 & $3.186(2440)$ & 561 & 103 \\
\hline HS 46 & 260 & 82 & FTD 76 & $3.186(2440)$ & 169 & 22 \\
\hline HS 47 & 254 & 22 & FTD 88 & $4.207(2154)$ & 775 & 173 \\
\hline HS 48 & 139 & 72 & FTD 88 & $4.207(2154)$ & 136 & 20 \\
\hline HS 49 & 306 & 58 & FTD 88 & $4.207(2154)$ & 366 & 53 \\
\hline HS 50 & 104 & 48 & FTD 88 & $4.207(2154)$ & 153 & 27 \\
\hline HS 51 & 146 & 66 & FTD 88 & $4.207(2154)$ & 156 & 23 \\
\hline HS 52 & 278 & 122 & FTD 88 & $4.207(2154)$ & 160 & 18 \\
\hline HS 53 & 78 & 29 & FTD 88 & $4.207(2154)$ & 189 & 41 \\
\hline HS 54 & 174 & 38 & FTD 88 & $4.207(2154)$ & 318 & 57 \\
\hline HS 56 & 231 & 48 & FTD 88 & $4.207(2154)$ & 334 & 54 \\
\hline HS 57 & 119 & 58 & FTD 88 & $4.207(2154)$ & 145 & 23 \\
\hline HS 58 & 176 & 84 & FTD 88 & $4.207(2154)$ & 148 & 20 \\
\hline HS 59 & 127 & 81 & FTD 88 & $4.207(2154)$ & 111 & 16 \\
\hline HS 60 & 258 & 149 & FTD 88 & $4.207(2154)$ & 122 & 13 \\
\hline ZA 3 & 113 & 22 & FTD 111 & $5.17+(700)$ & 435 & 103 \\
\hline $\mathrm{ZA} 7$ & 191 & 66 & FTD 111 & $5.17+(700)$ & 249 & 37 \\
\hline $2 A 10$ & 116 & 19 & FTD 111 & $5.17+(700)$ & 514 & 129 \\
\hline $\mathrm{ZA} 11$ & 88 & 42 & FTD 111 & $5.17+(700)$ & 181 & 35 \\
\hline $\mathrm{ZA} 14$ & 188 & 41 & FTD 111 & $5.17+(700)$ & 390 & 69 \\
\hline ZB 4 & 191 & 175 & FTD 111 & $5.17+(700)$ & 95 & 11 \\
\hline ZB 6 & 238 & 86 & FTD 111 & $5.17+(700)$ & 238 & 31 \\
\hline ZB 7 & 83 & 30 & FTD 111 & $5.17+(700)$ & 238 & 51 \\
\hline ZB 16 & 169 & 71 & FTD 111 & $5.17+(700)$ & 205 & 30 \\
\hline ZB 19 & 191 & 140 & FTD 111 & $5.17+(700)$ & 118 & 14 \\
\hline ZB 29 & 437 & 114 & FTD 111 & $5.17+(700)$ & 327 & 37 \\
\hline ZD 13 & 194 & 16 & FTD 104 & $3.20(662)$ & 626 & 165 \\
\hline ZE I & 137 & 38 & FTD 104 & $3.20(662)$ & 193 & 36 \\
\hline $\mathrm{ZE} 7$ & 156 & 38 & FTD 104 & $3.20(662)$ & 219 & 40 \\
\hline
\end{tabular}


Table 1. (cont.)

\begin{tabular}{|c|c|c|c|c|c|c|}
\hline Crystal & $N_{\mathrm{s}}$ & $N_{\mathrm{i}}$ & Irradiation & $\begin{array}{l}\rho_{\mathrm{d}} / 10^{5 *} \\
\left(\mathrm{t} \mathrm{cm}^{-2}\right)\end{array}$ & $\begin{array}{c}\text { Age } \\
(\mathbf{M a})\end{array}$ & $\begin{array}{l}\text { s.d. } \\
\text { (Ma) }\end{array}$ \\
\hline ZE 8 & 313 & 111 & FTD 104 & $3.20(662)$ & 151 & 18 \\
\hline ZE 10 & 103 & 34 & FTD 104 & $3.20(662)$ & 162 & 33 \\
\hline ZE 14 & 211 & 71 & FTD 104 & $3.20(662)$ & 159 & 23 \\
\hline ZI 2 & 556 & 110 & FTD 104 & $3.20(662)$ & 268 & 30 \\
\hline ZI 16 & 106 & 53 & FTD 104 & $3.20(662)$ & 108 & 19 \\
\hline $\mathrm{ZJ} 1$ & 184 & 87 & FTD 111 & $5.17+(700)$ & 183 & 25 \\
\hline $\mathrm{ZJ} 13$ & 528 & 186 & FTD 111 & $5.17 \dagger(700)$ & 244 & 23 \\
\hline $\mathrm{ZJ} 21$ & 195 & 20 & FTD 111 & $5.17 \dagger(700)$ & 802 & 191 \\
\hline ZJ 26 & 84 & 20 & FTD 111 & $5.17+(700)$ & 358 & 90 \\
\hline ZJ 27 & 102 & 33 & FTD 111 & $5.17+(700)$ & 265 & 54 \\
\hline ZJ 44 & 85 & 66 & FTD 111 & $5.17+(700)$ & 112 & 19 \\
\hline ZL 4 & 145 & 20 & FTD 111 & $5.17+(700)$ & 605 & 146 \\
\hline $\mathrm{ZL} 10$ & 160 & 111 & FTD 111 & $5.17 \dagger(700)$ & 125 & 16 \\
\hline ZL 12 & 168 & 30 & FTD 111 & $5.17 \dagger(700)$ & 473 & 95 \\
\hline ZL 13 & 232 & 21 & FTD 111 & $5.17+(700)$ & 902 & 203 \\
\hline ZL 14 & 125 & 50 & FTD 111 & $5.17+(700)$ & 215 & 37 \\
\hline ZL 16 & 84 & 22 & FTD 111 & $5.17+(700)$ & 326 & 79 \\
\hline ZL 28 & 152 & 101 & FTD 111 & $5.17+(700)$ & 131 & 17 \\
\hline
\end{tabular}

* $\rho_{\mathrm{d}}$ is the detector track density from the glass standard dosimeter (tracks per $\mathrm{cm}^{2}$ ). No. of tracks counted shown in brackets.

+ Inferred notional value obtained by including zircons HS 23-28 in the irradiation as a standard and comparing with $\rho_{\mathrm{d}}$ for SRM 612 in irradiation FTD 84.

Table 2. Results of fission track dating of detrital zircon grains extracted from a sample (BK 1761) of the Netherside Sand

\begin{tabular}{|c|c|c|c|c|c|c|}
\hline Crystal & $N_{\mathrm{s}}$ & $N_{\mathrm{i}}$ & Irradiation & $\begin{array}{l}\rho_{\mathrm{d}} / 10^{5 *} \\
\left(\mathrm{t} \mathrm{cm} \mathrm{cm}^{-2}\right)\end{array}$ & $\begin{array}{c}\text { Age } \\
\text { (Ma) }\end{array}$ & $\begin{array}{l}\text { s.d. } \\
\text { (Ma) }\end{array}$ \\
\hline AA 1 & 138 & 41 & FTD 111 & $5.17+(700)$ & 288 & 52 \\
\hline AA 2 & 446 & 86 & FTD 111 & $5.17+(700)$ & 439 & 54 \\
\hline AA 3 & 169 & 71 & FTD 111 & $5.17+(700)$ & 205 & 30 \\
\hline AA 4 & 144 & 25 & FTD 111 & $5.17 \dagger(700)$ & 486 & 107 \\
\hline AA 5 & 104 & 34 & FTD 111 & $5.17+(700)$ & 263 & 53 \\
\hline AA 6 & 179 & 53 & FTD 111 & $5.17 \dagger(700)$ & 289 & 47 \\
\hline AA 9 & 274 & 85 & FTD 111 & $5.17+(700)$ & 276 & 36 \\
\hline AA 10 & 154 & 22 & FTD 111 & $5.17 \dagger(700)$ & 586 & 135 \\
\hline AA 16 & 404 & 70 & FTD 111 & $5.17 \dagger(700)$ & 487 & 66 \\
\hline AA 17 & 168 & 31 & FTD 111 & $5.17+(700)$ & 458 & 91 \\
\hline AA 18 & 222 & 60 & FTD 111 & $5.17+(700)$ & 316 & $48 \mathrm{e}$ \\
\hline AA 20 & 114 & 81 & FTD 111 & $5.17 \dagger(700)$ & 122 & $18 \mathrm{e}$ \\
\hline BB 6 & 300 & 67 & FTD 111 & $5.17+(700)$ & 381 & 53 \\
\hline BB 16 & 218 & 61 & FTD 111 & $5.17+(700)$ & 301 & 45 \\
\hline BB 21 & 266 & 58 & FTD 111 & $5.17+(700)$ & 390 & 58 \\
\hline BB 25 & 266 & 133 & FTD 111 & $5.17+(700)$ & 173 & 19 \\
\hline $\mathrm{CC} 1$ & 270 & 107 & FTD 110 & $6.70(1394)$ & 280 & 33 \\
\hline $\mathrm{CC} 4$ & 116 & 40 & FTD 110 & $6.70(1394)$ & 321 & 60 \\
\hline CC 24 & 383 & 169 & FTD 110 & $6.70(1394)$ & 252 & 24 \\
\hline CC 25 & 309 & 173 & FTD 110 & $6.70(1394)$ & 200 & 20 \\
\hline DD 2 & 228 & 102 & FTD 110 & $6.70(1394)$ & 249 & 30 \\
\hline DD 7 & 81 & 40 & FTD 110 & $6.70(1394)$ & 226 & $44 \mathrm{e}$ \\
\hline DD 8 & 67 & 52 & FTD 110 & $6.70(1394)$ & 145 & 27 \\
\hline DD 9 & 94 & 34 & FTD 110 & $6.70(1394)$ & 307 & $62 \mathrm{e}$ \\
\hline DD 11 & 85 & 21 & FTD 110 & $6.70(1394)$ & 444 & 109 \\
\hline DD 12 & 96 & 40 & FTD 110 & $6.70(1394)$ & 267 & $51 \mathrm{e}$ \\
\hline DD 13 & 214 & 45 & FTD 110 & $6.70(1394)$ & 519 & 86 \\
\hline EE 2 & 239 & 155 & FTD 110 & $6.70(1394)$ & 173 & 18 \\
\hline EE 5 & 369 & 232 & FTD 110 & $6.70(1394)$ & 178 & 16 \\
\hline EE 6 & 178 & 35 & FTD 110 & $6.70(1394)$ & 553 & 103 \\
\hline FF 10 & 236 & 192 & FTD 110 & $6.70(1394)$ & 138 & 14 \\
\hline FF 20 & 355 & 180 & FTD 110 & $6.70(1394)$ & 220 & 21 \\
\hline FF 23 & 92 & 67 & FTD 110 & $6.70(1394)$ & 154 & 25 \\
\hline GG 3 & 184 & 69 & FTD 116 & $5.38(1119)$ & 239 & $34 \mathrm{e}$ \\
\hline GG 4 & 149 & 40 & FTD 116 & $5.38(1119)$ & 331 & 60 \\
\hline GG 5 & 130 & 43 & FTD 116 & $5.38(1119)$ & 270 & 48 \\
\hline GG 6 & 129 & 66 & FTD 116 & $5.38(1119)$ & 176 & 27 \\
\hline GG 9 & 80 & 18 & FTD 116 & $5.38(1119)$ & 393 & 103 \\
\hline GG 10 & 58 & 33 & FTD 116 & $5.38(1119)$ & 158 & 35 \\
\hline GG 13 & 51 & 26 & FTD 116 & $5.38(1119)$ & 176 & 43 \\
\hline GG 16 & 102 & 57 & FTD 116 & $5.38(1119)$ & 161 & $27 \mathrm{e}$ \\
\hline GG 17 & 130 & 38 & FTD 116 & $5.38(1119)$ & 305 & $57 \mathrm{e}$ \\
\hline GG 19 & 143 & 50 & FTD 116 & $5.38(1119)$ & 256 & $43 e$ \\
\hline GG 20 & 112 & 44 & FTD 116 & $5.38(1119)$ & 228 & $41 \mathrm{e}$ \\
\hline
\end{tabular}

* $\rho_{\mathrm{d}}$ is the detector track density from the standard glass dosimeter (tracks per $\mathrm{cm}^{2}$ ). No. of tracks counted shown in brackets.

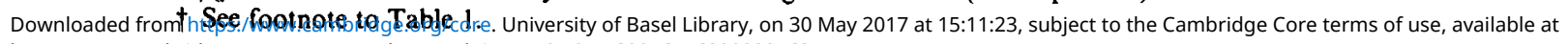




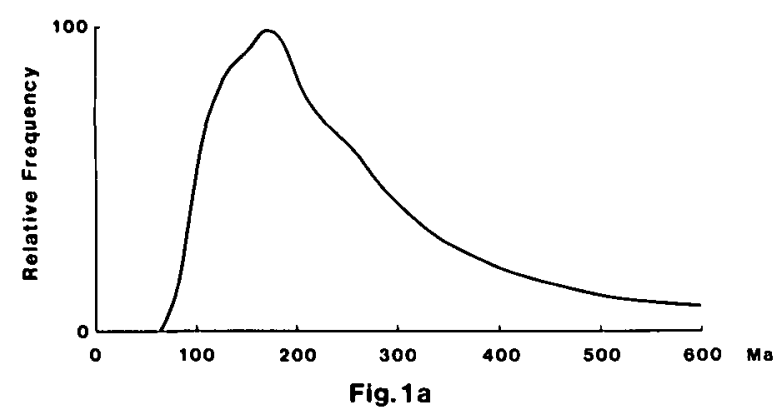

Figure $1 a$. Frequency distribution BK 1762,90 crystals. Peak at $163 \mathrm{Ma}$.

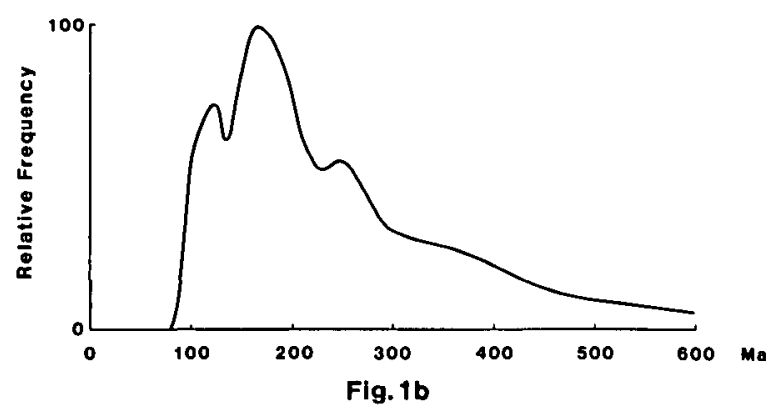

Figure $1 b$. As Figure $1 a$ but s.d. multiplied by 0.5 . Peaks at $119,160,243,309^{*}$ Ma. ${ }^{*}$ Maximum not well defined.

findings from Figures 1 and 2 are set out in summary form in Table 3.

\section{Geochronometric discussion}

The computer analysis was aimed at extracting the greatest amount of information available, in the form of a most likely identification of any groupings of ages

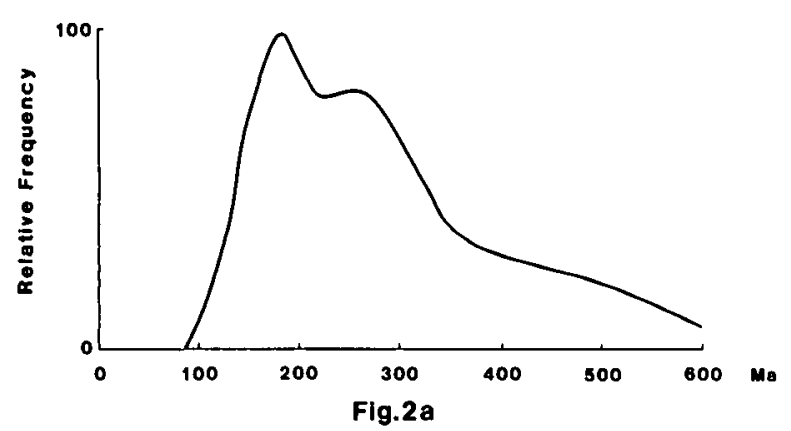

Figure $2 a$. Frequency distribution BK 1761, 44 crystals. Peaks at 179, $253 \mathrm{Ma}$.

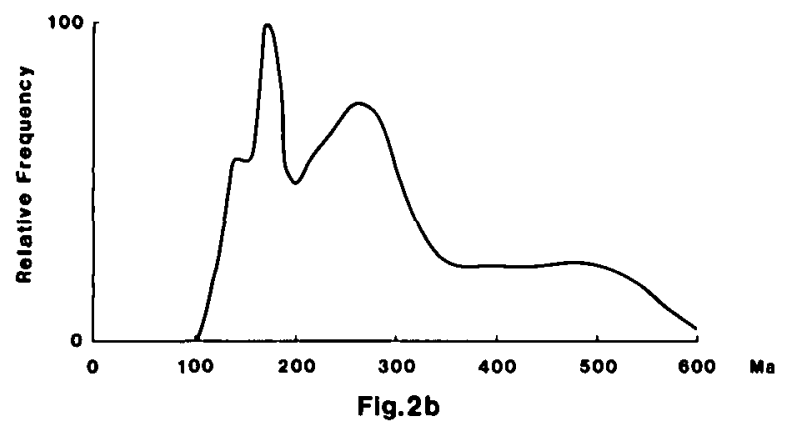

Figure $2 b$. As figure $2 a$ but s.d. multiplied by 0.5 . Peaks at $141,173,257,393^{*}-475^{*}$ Ma. *Maximum not well defined. of the zircons in the sandstone. It became apparent that the most secure statistical approach was to aim at a large size of sample. This was achieved for BK 1762, but for BK 1761 the sample is limited by the scarcity of zircons of adequate quality. The results for the latter rock must therefore be considered more tentative than those for BK 1762.

The strongest indications of ages of source material are, for BK 1762 around $160 \mathrm{Ma}$ (late mid Jurassic), and for BK 1761 around $175 \mathrm{Ma}$ (early mid Jurassic) and 257-277 Ma (Permian). Both rocks show evidence of older material, and (in the case of BK 1762) some younger material encroaching near to or below the accepted age of early Wealden sedimentation. The oldest ages suggest a wide range of possible origin for some of the zircons. The very youngest ages are more difficult to explain. They may indicate that some zircons were inadequately etched despite the care that was taken. There is no reason to suspect contamination at any stage.

\section{Palaeogeographical discussion}

In the Weald of southern England, Allen (1975, 1981) suggests that two episodes of major fan-building produced the Ashdown and Lower Tunbridge Wells sandy outwash plains in the Lower Cretaceous. During both episodes, outwash spreading south from Londinia encountered and intermingled with similar deposits building north from Armorica. Allen's interpretation is based upon a careful study of the larger clasts and mineral suites contained in these rocks. For example, he finds that in Lower Wealden times sandy detritus

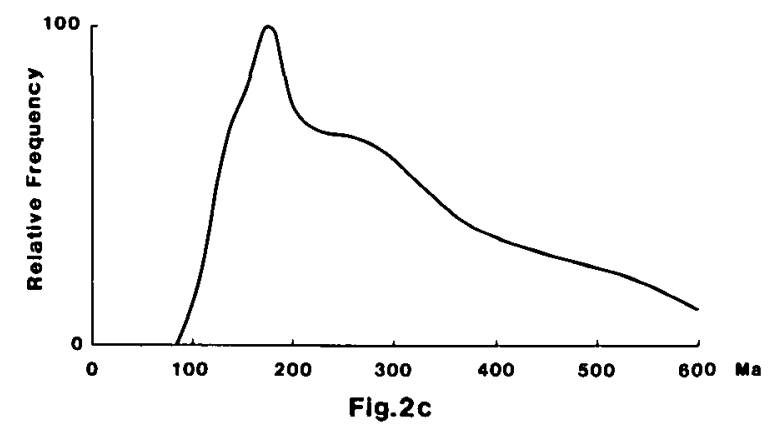

Figure $2 c$. Frequency distribution BK 1761, 34 crystals. Peaks at $177,259 \mathrm{Ma}$.

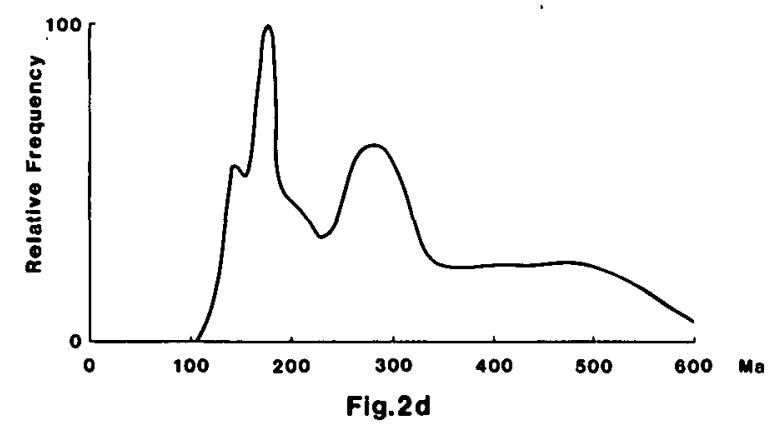

Figure $2 d$. As Figure $2 c$ but s.d. multiplied by 0.5 . Peaks at $141,175,277,398^{*}-453^{*}$ Ma. ${ }^{*}$ Maximum not well defined. 
Table 3. Frequency modes indicated by the histograms

\begin{tabular}{|c|c|c|c|c|c|c|c|}
\hline \multirow{3}{*}{$\begin{array}{l}\text { Rock } \\
\text { BK } 1762 \\
\text { BK } 1762\end{array}$} & \multirow{3}{*}{$\begin{array}{c}\begin{array}{c}\text { No. of } \\
\text { zircons }\end{array} \\
90 \\
90\end{array}$} & \multirow{3}{*}{$\begin{array}{c}\begin{array}{c}\text { s.d. } \\
\text { multiplier }\end{array} \\
1 \\
0.5\end{array}$} & \multirow{3}{*}{$\begin{array}{r}\begin{array}{r}\text { See } \\
\text { Fig.: }\end{array} \\
1 a \\
1 b\end{array}$} & \multicolumn{4}{|c|}{$\begin{array}{l}\text { Age frequency modes }(\mathrm{Ma}) \\
\text { (relative heights of maxima in parentheses }\end{array}$} \\
\hline & & & & - & 163 & - & - \\
\hline & & & & $\begin{array}{r}119 \\
(74)\end{array}$ & $\begin{array}{l}160 \\
(100)\end{array}$ & $\begin{array}{l}243 \\
(56)\end{array}$ & $\begin{array}{l}309^{*} \\
(36)\end{array}$ \\
\hline BK 1761 & 44 & 1 & $2 a$ & - & $\begin{array}{c}179 \\
(100)\end{array}$ & $\begin{array}{l}253 \\
(86)\end{array}$ & - \\
\hline BK 1761 & 44 & 0.5 & $2 b$ & $\begin{array}{l}141 \\
(59)\end{array}$ & $\begin{array}{c}173 \\
(100)\end{array}$ & $\begin{array}{l}257 \\
(77)\end{array}$ & $\begin{array}{l}393^{*}-475^{*} \\
(22,25)\end{array}$ \\
\hline BK 1761 & 34 & 1 & $2 c$ & - & $\begin{array}{l}177 \\
(100)\end{array}$ & $\begin{array}{l}259 \\
(68)\end{array}$ & - \\
\hline BK 1761 & 34 & 0.5 & $2 d$ & $\begin{array}{l}141 \\
(58)\end{array}$ & $\begin{array}{c}175 \\
(100)\end{array}$ & $\begin{array}{l}277 \\
(63)\end{array}$ & $\begin{array}{c}398^{*}-453^{*} \\
(24,25)\end{array}$ \\
\hline
\end{tabular}

Relative heights of maxima are in terms of largest $=100$.

- Maximum not well defined, see Figures.

with high staurolite/kyanite ratios, indicative of high-grade metamorphic source rocks, entered southern England from the south but is confined to Sussex. Other lines of evidence include the petrography of the larger clasts and the argon-40/argon-39 ages of detrital tourmaline and other minerals (Allen, 1949, $1972,1975,1981)$.

A stratigraphical comparison between the age distribution of detrital zircons in the two Wealden sandstone samples we examined is given in Table 4. Zircon is a common accessory mineral in many volcanic and plutonic igneous rocks and in some metamorphic rocks. It is a resistant mineral during denudation. Thus detrital zircon is also common and may be reworked through many sedimentary cycles. Numerous reworked zircon grains are likely to be present in our samples. Nevertheless, it is most probable that the principal modal concentrations in the zircon age spectra represent either direct derivation from rock outcrops of the appropriate ages or reworking throughintermediatesedimentsoutcropping on approximately the same azimuth as the ultimate source rocks. Thus, taking into consideration the known Upper Palaeozoic and Mesozoic geology of western Europe, it would be reasonable to expect that outcrops of penecontemporaneous Lower Cretaceous, late mid Jurassic, late Permian/early Triassic and late Carboniferous rocks were important in the derivation of the Top Ashdown Sandstone sample and that, in addition, small areas of older Palaeozoic and Precambrian rocks might have been exposed at this time. Alternatively, some or all of these recognizable zircon age groups could have been concentrated in, and then reworked from, sedimentary rocks of intermediate age and location outcropping in the source massifs during lower Wealden times. The absence of prominent concentrations of zircons of late Jurassic/early Cretaceous, Lower Permian or Caledonian age is also important in characterizing the provenance of this rock.

The necessary combination of primary and/or secondary source outcrops to provide the zircon age distribution found in the Top Ashdown Sandstone was not present in the Londinia massif in early Wealden times because Permo-Trias, Lower and Middle Jurassic strata and Variscan granites must be virtually absent from the Londinian succession. To the south and southeast, however, rocks of the required ages are present, either in Armorica or beyond. Mid Jurassic volcanoes have been reported in the Massif Central and extensive late Permian/early Triassic volcanics occur in Aquitaine, Biscay and Iberia (Carte géologique

Table 4. Stratigraphical comparison between the age distribution of detrital zircons in the two samples of Lower Cretaceous sandstones (see Figures $1 b$ and $2 d$ )

\begin{tabular}{|c|c|c|}
\hline & $\begin{array}{l}\text { BK } 1762 \\
\text { Dallington }\end{array}$ & $\begin{array}{l}\text { BK } 1761 \\
\text { Netherside }\end{array}$ \\
\hline 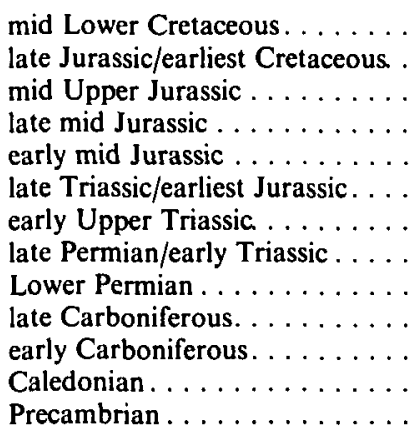 & 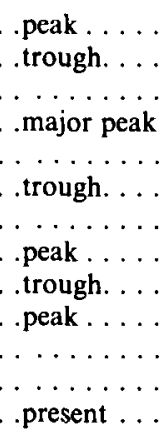 & 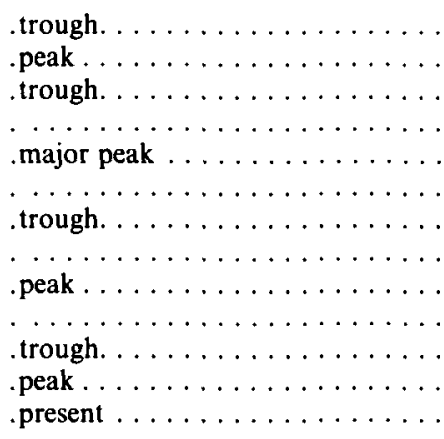 \\
\hline
\end{tabular}


de la France et de la marge continentale, 1980). Suitable late Carboniferous, older Palaeozoic and Precambrian source rocks outcrop in Armorica itself. Whilst the younger zircons are almost certainly derived from volcanics and their associated intrusions, the late Carboniferous zircons are more likely to have their main source in the granites and related post-orogenic intrusions of the Armorican sector of the Variscan fold belt (granites, mostly between 300 and $330 \mathrm{Ma}$, Chauris et al. 1956; Graindor \& Wasserburg, 1962; Leutwein et al. 1969; and lamprophyres, around $300 \mathrm{Ma}$, e.g. Lees, 1974). The actual source volcanoes from which the Lower Cretaceous zircons were derived are as yet unknown, but explosive eruptions from volcanoes in the Channel Approaches may have spread ash over wide areas (Jeans et al. 1982). (Lower Cretaceous volcanism is also known in the northern North Sea, see Dixon, Fitton \& Frost 1981.)

The Bathonian Fuller's Earth of southern Britain is not regarded as a probable source of the large population of mid Jurassic zircons in the Top Ashdown sample because at its present outcrops it is almost free of zircon (R. J. Merriman pers. comm., and our own observations) and was probably poorly exposed in early Wealden times. Major occurrences of mid Jurassic basic volcanism (with ages around $165 \mathrm{Ma}$ ) are known in both the Celtic and North Sea areas (Howitt, Aston \& Jaque, 1975; Woodhall \& Knox, 1979; Harrison et al. 1979, Dixon, Fitton \& Frost, 1981) and the possibility that zircons of this age were introduced into the Weald from either Londinia or Armorica after reworking from Upper Jurassic sandstones cannot be ignored entirely. If, however, part or all of the late mid Jurassic zircon component of the Top Ashdown Sandstone was derived from either the north or west, it is puzzling that there is no evidence of late Jurassic/early Cretaceous (probably derived from the southern North Sea), Lower Permian (from Cornubia) and broadly Caledonian zircon components, all of which appear in the Netherside Sand sample. Thus, it would appear that examination of the age spectrum of the detrital zircon population of the Top Ashdown Sandstone sample does provide strong confirmatory evidence of Allen's southerly derivation for much, if not all, of its clastic detritus.

In later Wealden times in the western Weald, environmental conditions were such as to make deposition predominantly argillaceous. Short-lived arenaceous incursions did occur, however, and the Netherside Sand is one of several such intercalations within the Weald Clay Group. Allen (1981) demonstrated the appearance of a major detrital component derived from Cornubia in these sands, and a less important component that appears to have been brought in from the north along the northwestern shoreline of Londinia by invasions of the Boreal Sea. Armorican debris seems totally absent. Argon- 40/argon-39 ages of $258 \pm 11,207 \pm 16$ or $237 \pm 11$ and $>372 \pm 40 \mathrm{Ma}$ obtained from detrital tourmaline (Allen, 1975) indicate a combination of Permo-Triassic and late Caledonian source rocks.

The zircon age spectrum of our Netherside Sand sample is quite different from that of the Top Ashdown Sandstone: it suggests either that extensive outcrops of late Jurassic/early Cretaceous, early mid Jurassic and early Permian volcanics are likely to have been present in its source areas or that zircons derived from them have been reworked from intermediate sediments. Zircons derived from the Caledonian fold belt are an important minor component. Precambrian zircons derived either directly or by reworking are also present as a minor component. Whilst early Permian volcanism is known in Cornubia (Exeter volcanics) (Tidmarsh, 1932; Miller, Shibata \& Munro, 1962; Miller \& Mohr, 1964) and volcanic clasts in the Lower Permian breccias and conglomerates of Devon (see Hatch, Wells \& Wells, 1961, p. 484; Laming, 1966; Cosgrove \& Elliott, 1976), neither mid nor late Jurassic volcanism has been recorded there. The source vents from which the Bathonian Fuller's Earth was erupted are unknown. The mid Jurassic zircons in our sample could have the same derivation. Nevertheless, it is still possible that many of the Jurassic and older zircons in the Netherside Sand were derived ultimately from further afield, either from the northern North Sea and from Caledonian Britain via the agency of the arm of the Boreal Sea, or from volcanism occurring in the Fastnet/Channel Approaches area or from as far away as the Mid Atlantic Rift. Possible source volcanics of Lower Permian and Mid Jurassic ages are widespread in the North Sea (Dixon, Fitton \& Frost, 1981), but we have seen no reports of volcanism of late Jurassic/earliest Cretaceous age from the northern North Sea. Jurassic volcanism occurred frequently along the Mid Atlantic Rift zone. The Zuidwal volcano in Holland is $144 \mathrm{Ma}$ old (Dixon, Fitton \& Frost, 1981) and ashes of this age could have been reworked from Londinia and elsewhere in the north to provide a zircon component around that age consistent with our $141 \mathrm{Ma}$ peak. Thus, it would appear that the zircon age spectrum of the Netherside Sand probably indicates a combination of Cornubian, Londinian and more distant westerly and/or northerly provenance. The indications of southerly provenance, so clearly seen in the Top Ashdown Sandstone, are totally absent. The palaeogeographical conclusions outlined above are compatible with the model proposed by Allen (1981).

\section{Conclusions}

Fission track ages were obtained from the individual detritalzircon crystals in the heavy mineral concentrates extracted from two Lower Cretaceous sandstones occurring in the Weald of England. The distribution 
of ages within the two populations was analysed taking into account the estimated uncertainty of each individual age determination. The Top Ashdown Sandstone sample (BK 1762) shows a marked concentration of zircon ages around $160 \mathrm{Ma}$ (late Middle Jurassic) and lesser concentrations at both younger (119 Ma) and older ages (243 Ma and $309 \mathrm{Ma}$ ). These zircon concentrations can be compared with the groupings of ages in figure 10 of Allen, 1981, around $155 \mathrm{Ma}, 230 \mathrm{Ma}$ and $315 \mathrm{Ma}$. The contrast in relative abundance between Variscan and mid Jurassic ages in the two samples presumably results from the virtual absence of tourmaline in the mid Jurassic volcanic source rocks. Much older, often metamict, zircons are also present. The oldest datable crystal had an apparent age of $902 \pm 203 \mathrm{Ma}$. This compares well with the two oldest (tourmaline) dates in figure 10 of Allen, 1981, one of which, from the top Lower Tunbridge Wells Pebble Bed, was $918 \pm 83$ Ma (Allen, 1975 , p. 430). The distribution of zircon fission track ages from the Netherside Sand sample (BK 1761) on the other hand shows (slightly less certain) peak concentrations around $175 \mathrm{Ma}$ (early mid Jurassic) and 257-277 Ma (Lower Permian) with lesser concentrations around $141 \mathrm{Ma}$ (late Jurassic/earliest Cretaceous) and between 398 and $453 \mathrm{Ma}$ (Caledonian). Older and metamict zircons are present also in this rock.

As would be expected, the results obtained above show that the detrital zircons in these two Lower Cretaceous sandstones range from Mesozoic to Precambrian age. Nevertheless, it seems clear that, at the localities sampled, each horizon shows a quite different and distinct spectrum of zircon ages. Although much further work remains to be done, the results of this pilot study do prompt the suggestion that fission-track age spectra obtained from one or more of their detrital mineral populations may enable the characterization of individual sediments in a way that will prove useful for correlation purposes. The spectrum obtained from any rock that has not undergone post-depositional heating (due to deep burial or metamorphism) of sufficient intensity and duration to cause the annealing of fission tracks in its constituent mineral must be related directly to the provenance of the clastic detritus. The Wealden of southern England meets these requirements. It appears never to have been buried to more than $2 \mathrm{~km}$ : its cover probably never exceeded $1.5 \mathrm{~km}$ (Allen, 1981).

Thus, the zircon age spectra of the two rocks sampled can be used to show that (i) the source of the clastic detritus in the Top Ashdown Sandstone sample from Dallington was very largely to the south and southwest, in Armorica and beyond, and (ii) the provenance of the Netherside Sand sample from Northchapel is to be found in a mixture of westerly (Cornubian or even further afield) and northerly (northern Britain, the North Sea and/or Londinian) sources, thus supporting Allen's suggestions in 1975 and 1981.

Acknowledgments. The work was carried out at Birkbeck College, University of London, and partially supported by the N.E.R.C. A.J.H. acknowledges current financial support for fission track dating in Bern from the Nationalfonds zur Förderung der wissenschaftlichen Forschung. The sandstone samples were provided, as described, by P. Allen who also commented on a draft of this paper. Irradiations were carried out in the Herald reactor at Aldermaston by C. George and M. Hynes, and paid for by the N.E.R.C. Advice on computation was given by $P$. Hooker and J. R. Wheldon. A. Carter assisted with the computation and other work at Birkbeck College. The work was programmed for the CDC $6000 / 6600$ computer situated at the University of London Computer Centre and use was also made of the Sinclair ZX 81 and ZX Spectrum computers.

\section{References}

Allen, P. 1947. Notes on Wealden fossil soil-beds. Proceedings of the Geologists' Association 57, 303-14.

Allen, P. 1949. Wealden petrology: the Top Ashdown Pebble bed and the Top Ashdown Sandstone. Quarterly Journal of the Geological Society of London 104, 257-321.

Allen, P. 1959. The Wealden environment: Anglo-Paris basin. Philosophical Transactions of the Royal Society B 242, 283-346.

Allen, P. 1972. Wealden detrital tourmaline: implications for northwestern Europe. Journal of the Geological Society of London 128, 273-88.

Allen, P. 1975. Wealden of the Weald: a new model. Proceedings of the Geologists' Association 86, 389-436.

Allen, P. 1981. Pursuit of Wealden models. Journal of the Geological Society of London 138, 375-405.

Carte géologique de la France et de la marge continentale à l'échelle de 1/1500000 (including Notice Explicative). 1980. Orléans: Bureau de Recherches Géologiques et Minières.

Chauris, L., Dangeard, L., Graindor, M. J. \& Lapparent, A. F. 1956. Les principaux batholites granitiques du Bocage normand sont antérieurs à la transgression cambrienne. Compte rendu sommaire des séances de la Société Géologique de France 243, 77-80.

Cosgrove, M. E. \& Elliott, M. H. 1976. Suprabatholithic volcanism of the southwest England granites. Proceedings of the Ussher Society 5, 76-80.

Dixon, J. E., Fitron, J. G. \& Frost, R. T. C. 1981. The tectonic significance of post-Carboniferous igneous activity in the North Sea Basin. In Petroleum Geology of the Continental Shelf of North West Europe (ed. L. V. Illing and G. D. Hobson), pp. 121-37. London: Institute of Petroleum.

Gleadow, A. J. W., Hurford, A. J. \& Quaife, R. D. 1976. Fission track dating of zircon: improved etching techniques. Earth and Planetary Science Letters 33, 273-6.

Gleadow, A. J. W. \& Lovering, J. F. 1977. Geometry factor for external track detectors in fission track dating. Nuclear Track Detection 1, 99-106.

GraindoR, M. J. \& WasSERbuRG, G. J. 1962. Déterminations d'âges absolus dans le nord du Massif armoricain. Compte rendu sommaire des séances de la Société Géologique de France 254, 3875-7. 
Green, P. F. 1981. A new look at statistics in fission track dating. Nuclear Tracks 5, 77-80.

Harrison, R. K., Jeans, C. V. \& Merriman, R. J. 1979. Mesozoic igneous rocks, hydrothermal mineralisation and volcanogenic sediments in Britain and adjacent regions. Bulletin of the Geological Survey of Great Britain 70, 57-69.

Hatch, F. H., Wells, A. K. \& Wells, M. K. 1961. The Petrology of the Igneous Rocks. London: Murby.

HowItT, F , Aston, E. R. \& JAQUE, M. 1975. The occurrence of Jurassic Volcanics in the North Sea. In Petroleum and the Continental Shelf of North West Europe (ed. A. W. Woodland), pp. 379-88. London: Institute of Petroleum.

Hurford, A. J. \& Gleadow, A. J. W. 1977. Calibration of fission track dating parameters. Nuclear Track Detection 1, 41-8.

Hurford, A. J. \& Green, P. F. 1981. A reappraisal of neutron dosimetry and uranium-238 $\lambda_{\mathrm{f}}$ values in fission track dating. Nuclear Tracks 5, 53-61.

Hurford, A. J. \& Green, P. F. 1983. The Zeta calibration of fission track dating. Isotope Geoscience 1, 285-317.

Jeans, C. V., Merriman, R. J., Mitchell, J. G. \& Bland, D. J. 1982. Volcanic Clays in the Cretaceous of Southern England and Northern Ireland. Clay Minerals $17,105-56$.
LAMING, D. J. C. 1966. Imbrication, palaeocurrents and other sedimentary features in the Lower New Red Sandstone, Devonshire, England. Journal of Sedimentary Petrology 36, 940-59.

LEES, G. J. 1974. Petrochemistry of the mica-lamprophyres (minettes) of Jersey (C.I.). Proceedings of the Ussher Society 3, 149-55.

Leutwein, F., Chauris, L., Sonet, J. \& Zimmerman, J.-L. 1969. Etudes géochronologiques et géotectoniques dans le Nord-Finistère (Massif Armoricain). Sciences de la Terre 14, 329-58.

Miller, J. A. \& MoHr, P. A. 1964. Potassium-argon measurement on the granites and some associated rocks from southwest England. Geological Journal 1, 105-26.

Miller, J. A., Shibata, K. \& Munro, M. 1962. The potassium-argon age of the lava at Killerton Park, near Exeter. Geophysical Journal 6, 394-6.

Tidmarsh, W. G. 1932. The Permian Lavas of Devon. Quarterly Journal of the Geological Society of London 28, 712-42.

Woodhall, D. \& KNox, R.W. O'B. 1979. Mesozoic volcanism in the North Sea and adjacent areas. Bulletin of the Geological Survey of Great Britain 70, 34-56. 